\title{
Respons Fenologi Tumbuhan terhadap Taburan Hujan di Johor Menggunakan Data Indeks Tumbuhan Satelit MODIS-Aqua
}

(Vegetation Phenology Response towards Rainfall Distribution using MODIS-Aqua Vegetation Satellite Index Data)

\author{
AMIRAH AUDADI MADZEN* \& LAM KUOK CHOY
}

\begin{abstract}
ABSTRAK
Fenologi tumbuhan menggambarkan fasa kitaran hidup atau aktiviti tumbuhan dan adalah penting untuk memahami interaksinya dengan iklim. Kajian dilakukan untuk mengenal pasti respons fenologi tumbuhan dan metrik fenologi hutan dipterokarpa, kelapa sawit dan pokok getah menggunakan data indeks tumbuhan Enhanced Vegetation Index (EVI) daripada MODIS-Aqua (produk MYD13Q1) dan purata hujan bulanan sepanjang tahun 2007 dan 2009 di negeri Johor. Pola hujan pada tahun 2007 menunjukkan taburan hujan normal, manakala tahun 2009 mengalami kekurangan hujan sepanjang tempoh sebelas tahun (2000-2010). Hasil mendapati tren EVI hutan dipterokarpa lebih bervariasi pada 2009 dengan nilai EVI antara 0.39-0.64 berbanding tren pada 2007 yang tekal dengan nilai EVI antara 0.33-0.57. Tren fenologi kelapa sawit pada 2007 lebih kerap mengalami turun naik berbanding pada 2009, masing-masing dengan EVI antara 0.45-0.71 dan 0.5-0.74. Corak fenologi pokok getah pada kedua-dua tahun kajian adalah sama dan julat EVI pada 2009 adalah lebih kecil berbanding 2007, masing-masing dengan EVI antara 0.39-0.62 dan 0.30-0.73. Pengaruh masa susulan ke atas tahap kehijauan tumbuhan telah dikesan, khususnya selepas peristiwa hujan lebat dalam dua tahun tersebut dan sedikit sebanyak mempengaruhi nilai korelasi antara pemboleh ubah purata hujan bulanan dengan EVI tumbuh-tumbuhan. Permulaan dan pengakhiran musim pertumbuhan hutan dipterokarpa bagi kedua-dua tahun berlaku dalam bulan yang sama, iaitu Februari (permulaan musim) dan Disember (pengakhiran musim). Tidak wujud perbezaan yang ketara antara panjang musim pertumbuhan kelapa sawit bagi kedua-dua tahun, iaitu hanya 32 hari lebih panjang pada 2007 berbanding 2009. Musim pertumbuhan pokok getah pula adalah lebih panjang pada 2007 dan lebih singkat pada 2009, masing-masing 176 hari dan 113 hari.
\end{abstract}

Kata kunci: EVI; fenologi tumbuhan; metrik fenologi; MODIS; musim pertumbuhan

\section{ABSTRACT}

Vegetation phenology describes the plant life cycle or activity and it is important to understand it's interactions with climate. This study was conducted to identify plant phenological responses to average monthly rainfall and to extract the phenology metrics for dipterocarp forest, oil palms and rubber trees by using EVI vegetation indices from MODIS-Aqua (product MYD13Q1) and an average of monthly rainfall for 2007 and 2009. Rainfall patterns in 2007 showed normal rainfall distribution whilst in 2009 experienced less rain in a period of eleven years (2000-2010). The result showed that the EVI of the dipterocarp forest is varied in 2009 with EVI value ranges 0.39-0.64 compared to the more consistent EVI values of 0.33-0.57 in 2007. The phenological trends of oil palms fluctuate in 2007 compared to 2009 with EVI at 0.45-0.71 and 0.5-0.74, respectively. Phenological patterns of rubber trees in both years showed similar trend and the EVI range of 2009 was smaller than in 2007 with value of 0.39-0.62 and 0.30-0.73, respectively. The effect of lag period on vegetations' greenness was detected, especially after heavy rain period in both years which affects the correlation values between the average rainfall and EVI. The start and end of growing season of the dipterocarp forest for both years occurred in February and December. There is no clear difference between the lengths of season for oil palms in both years, which is 32 days longer in 2007 compared to 2009. Length of season for rubber tree is longer in 2007 and significantly shorter in 2009 at 176 and 113 days, respectively.

Keywords: EVI; growing season; MODIS; phonological matrics; vegetation phenology

\section{PENGENALAN}

Kedinamikan fenologi ekosistem daratan mencerminkan wujud reaksi antara biosfera bumi dengan kedinamikan iklim bumi (Menzel et al. 2006; Zhang et al. 2003) dan merupakan maklumat penting dalam memahami interaksi antara biosfera dan iklim serta impaknya dalam ruang dan skala yang berbeza (Yu et al. 2014). Fenologi tumbuhan merupakan ekspresi kitaran musiman tumbuh-tumbuhan yang dapat menyumbang maklumat penting berkaitan keadaan semasa tumbuhan serta hubungannya dengan perubahan iklim (Farooq 2012). Kini, penyelidikan fenologi tumbuhan menggunakan sistem penderia satelit dengan resolusi temporal yang tinggi semakin mendapat sambutan. Beberapa pendekatan penderiaan jauh telah 
diuji dan berjaya diaplikasikan dalam kajian perubahan komposisi, litupan dan struktur tumbuhan. Penderia satelit seperti Advanced Very High Resolution Radiometer (AVHRR), Moderate Resolution Imaging Spectroradiometer (MODIS), Medium Resolution Imaging Spectrometer (MERIS) dan Satellite Pour l'Observation de la Terre Vegetation (SPOT VEGETATION) mampu merakam imej permukaan bumi pada resolusi ruang sederhana tetapi beresolusi temporal yang tinggi (Senf et al. 2013) dan kerap digunakan bagi mengenal pasti fasa fenologi tumbuhan. Perubahan yang berlaku pada tumbuh-tumbuhan dapat dianalisis menggunakan data siri masa penderiaan jauh seperti Normalized Difference Vegetation Index (NDVI) dan Enhanced Vegetation Index (EVI).

Di Malaysia, penggunaan teknologi penderiaan jauh dalam kajian fenologi tumbuhan masih kurang dilakukan. Kajian secara pemerhatian dan merekod perubahan musim pertumbuhan di plot kajian mengehadkan kajian kepada skala ruangan yang kecil berbanding penggunaan teknologi penderiaan jauh yang terangkum sehingga ke skala global. Kajian fenologi tumbuhan menggunakan pendekatan penderiaan jauh di kawasan tropika lembap menghadapi kekangan daripada segi gangguan litupan awan yang kerap dan kandungan aerosol yang tinggi. Faktor tersebut memberi kesan ke atas analisis temporal data penderiaan jauh dan merupakan antara penyebab fenologi tumbuhan di kawasan tropika lembap kurang didokumentasikan (Moreau \& Defourny 2012). Selain itu, perubahan iklim merupakan salah satu isu dalam bidang fenologi tumbuhan. Proses pertumbuhan, pembiakan dan kelangsungan hidup melalui kitar tumbuhan sememangnya bergantung kepada keadaan persekitaran yang dialami oleh tumbuh-tumbuhan (Sykes 2009) dan kajian mendapati fenologi tumbuhan serta toleransinya terhadap persekitaran adalah berbeza mengikut spesies tumbuhan (Han 2012).

Kebanyakan pengkaji kurang memberi perhatian terhadap fakta bahawa fenologi tumbuhan bukan sahaja responsif kepada suhu malah turut responsif kepada hujan.
Malaysia lazimnya menerima curahan hujan yang banyak sepanjang tahun turut mengalami taburan dan variasi musim sehingga menyebabkan wujud tahun-tahun yang mengalami kekurangan hujan (Sharifah Haslinda 2011). Selain itu, dianggarkan sebanyak 2830 spesies flora terdapat di Semenanjung Malaysia (Ng et al. 1990). Maka adalah relevan jika kajian fenologi tumbuhan dilakukan ke atas beberapa spesies tumbuhan di Malaysia bagi menguji sama ada wujud perbezaan toleransi terhadap persekitaran meskipun hidup dalam lingkungan kawasan yang sama. Sehubungan itu, matlamat utama artikel ini adalah untuk melaporkan perubahan intra-tahunan dan inter-tahunan fenologi hutan diterokarp, kelapa sawit dan getah bagi 2007 dan 2009 menggunakan data MODIS. Selain itu, respons fenologi tumbuhan terhadap purata hujan bulanan turut dijelaskan bagi memahami respons intra-tahunan terhadap kehadiran air dan mengesan perubahan jangka panjang tumbuhan tersebut.

\section{KAWASAN KAJIAN}

Kajian dijalankan di negeri Johor yang terletak di antara garisan longitud $102^{\circ} 29^{\prime} 22^{\prime \prime} \mathrm{T}$ dan $104^{\circ} 30^{\prime} 47^{\prime \prime} \mathrm{T}$ serta latitud $1^{\circ} 20^{\prime} 25^{\prime}$ 'U dan $2^{\circ} 49^{\prime} 42^{\prime \prime} \mathrm{U}$ (Rajah 1). Keluasan negeri Johor adalah $19016 \mathrm{~km}^{2}$ dan beriklim khatulistiwa dengan suhu seragam, kelembapan tinggi dan hujan yang banyak. Berdasarkan data cuaca Jabatan Meteorologi Malaysia dari 2000-2010, purata suhu tahunan negeri Johor adalah antara 26 hingga $27^{\circ} \mathrm{C}$, manakala purata hujan tahunan tertinggi direkodkan pada 2007 (2593.8 mm) dan purata hujan tahunan terendah pula direkodkan pada 2009 $(1,664.9 \mathrm{~mm})$. Sebahagian besar kawasan Johor terdiri daripada dataran tanah rendah dan topografi beralun yang kurang dari $200 \mathrm{~m}$ dan sebahagian lagi adalah kawasan berbukit dengan ketinggian kira-kira 180 hingga $600 \mathrm{~m}$ (timur, sebahagian tengah dan utara Johor) serta kawasan tanah tinggi dengan ketinggian melebihi $600 \mathrm{~m}$ (timur Johor). Sehingga 2012, lebih separuh kawasan Johor

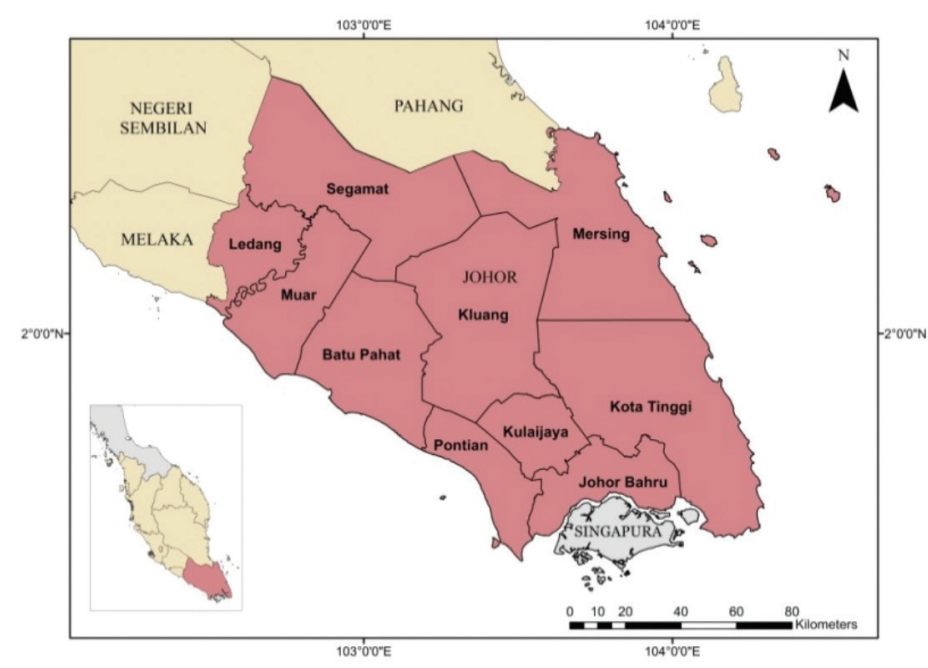

RAJAH 1. Negeri Johor 
dilitupi guna tanah pertanian $(59.1 \%)$ dan diikuti guna tanah perhutanan $(28.7 \%$ ) (Jabatan Perancangan Bandar dan Desa Semenanjung Malaysia 2012).

\section{DATA DAN METOD KAJIAN}

Data Enhanced Vegetation Index (EVI) daripada produk indeks tumbuhan MODIS-Aqua (MYD13Q1) dengan resolusi temporal 16 hari dan resolusi ruang $250 \mathrm{~m}$ telah digunakan untuk mengkaji pertumbuhan vegetasi. Sebanyak 46 data daripada produk MYD13Q1 (23 data per tahun) bagi 2007 dan 2009 telah diperoleh dari United States Geological Survey (USGS). EVI dibangunkan untuk mengoptimumkan isyarat tumbuh-tumbuhan dan memperbetulkan herotan pantulan cahaya yang disebabkan oleh zarah di ruang atmosfera dan kesan daripada pantulan latar tanih di bawah tumbuh-tumbuhan. Data EVI juga tidak mudah menjadi tepu berbanding NDVI (Tan et al. 2008), khususnya di kawasan hutan hujan dan kawasan lain yang mempunyai kandungan biojisim yang tinggi. Selain itu, kajian yang dijalankan turut menggunakan data purata hujan bulanan negeri Johor (2007 dan 2009) yang diperoleh dari Jabatan Meteorologi Malaysia menerusi cerapan dari stesenstesen pencerap di seluruh negeri Johor. Berdasarkan data hujan yang diperoleh, didapati pola hujan pada tahun 2007 menunjukkan hujan normal manakala pola hujan pada tahun 2009 menunjukkan berlaku kekurangan jumlah hujan bagi tempoh sebelas tahun (2000-2010).

Prapemprosesan Imej Set data EVI diekstrak daripada dataset produk MYD13Q1 dan melalui beberapa langkah prapemprosesan imej seperti pemeriksaan kualiti data, proses transformasi geometrik daripada unjuran sinusoidal kepada unjuran GDM 2000 MRSO Peninsular Malaysia, proses keratan imej dan pengubahan format. Setiap langkah tersebut dilakukan menerusi Model Builder pada perisian ArcGIS 10.3.

Proses Mengenal Pasti dan Mengekstrak Fenologi Spesies Tumbuhan Tiga spesies tumbuhan, iaitu hutan dipterokarpa, kelapa sawit dan getah dikenal pasti menerusi kaedah interpretasi visual pada imej Landsat TM tahun 2007 dan 2009 dengan menggunakan kombinasi komposit imej warna palsu jalur 4,5,3. Semakan ke atas lokasi sampel spesies tumbuhan yang telah dikenal pasti turut dilakukan menerusi aplikasi Google Earth. Keluk musiman dan metriks fenologi (permulaan musim, pengakhiran musim dan panjang musim pertumbuhan) bagi ketiga-tiga jenis tumbuhan diekstrak menggunakan perisian TIMESAT untuk dianalisis. Kaedah penyaringan Savitzky-Golay digunakan bagi melicinkan data mentah EVI.

Analisis Hubungan antara EVI dan Hujan Bulanan Kaedah analisis kolerasi Pearson diaplikasikan dalam mengkaji hubungan antara jumlah hujan bulanan tahun 2007 dan 2009 dengan EVI bagi ketiga-tiga spesies tumbuhan.
HASIL KAJIAN DAN PERBINCANGAN

RESPONS, METRIKS FENOLOGI DAN HUBUNGAN FENOLOGI DENGAN TREN HUJAN SEPANJANG 2007 DAN 2009

Hutan Dipterokarpa Penerimaan hujan yang tinggi dan tekal sepanjang 2007 menyebabkan tren EVI hutan dipterokarpa turut tekal, kurang bervariasi, bahkan nilai EVI adalah lebih rendah berbanding pada tahun 2009 meskipun purata hujan pada 2009 adalah lebih rendah berbanding 2007 (Rajah 2 dan 3). Faktor ketersediaan air menjadi pengaruh utama ke atas tren EVI yang malar dan rendah pada 2007. Ketersediaan air adalah faktor kukuh dan muktamad yang mempengaruhi fenologi bagi kebanyakan tumbuhan di hutan tropika dan wujud hubungan yang kuat antara fenologi hutan tropika dengan jumlah hujan selepas suatu tempoh musim kering (Shoko Sakai 2001; Van Shaik et al. 1993). Ini menunjukkan bahawa tren fenologi hutan di kawasan tropika adalah lebih bervariasi, khususnya selepas melalui tempoh musim kering.

Selain itu, fenologi hutan dipterokarpa pada 2007 menunjukkan terdapat masa susulan ke atas tahap kehijauan, iaitu hampir dua bulan selepas penerimaan hujan maksimum pada bulan Januari walaupun berlaku pengurangan hujan mendadak pada bulan berikutnya (Rajah 2). Penerimaan hujan maksimum pada bulan Mac 2009 juga menyebabkan EVI hutan dipterokarpa terus meningkat kira-kira dua bulan selepas itu walaupun berlaku pengurangan hujan pada bulan berikutnya (Rajah 3). Keputusan kajian ini adalah selari dengan Phompila et al. (2014) yang mendapati EVI hutan di Laos mula menunjukkan peningkatan dan memuncak pada bulan Oktober, iaitu dua bulan selepas peristiwa hujan maksimum pada bulan Julai. Beliau mendapati kesan masa susulan adalah disebabkan kelembapan tanah yang masih tersedia untuk pokok saka dan tumbuhan-tumbuhan renek di hutan tersebut.

Menurut Corlett dan Primack (2005), dipterokarpa di Asia cenderung untuk memiliki batang yang lurus dan licin serta tumbuh tinggi tanpa dedahan sehinggalah mencapai kanopi. Oleh sebab ciri-ciri pertumbuhan dan

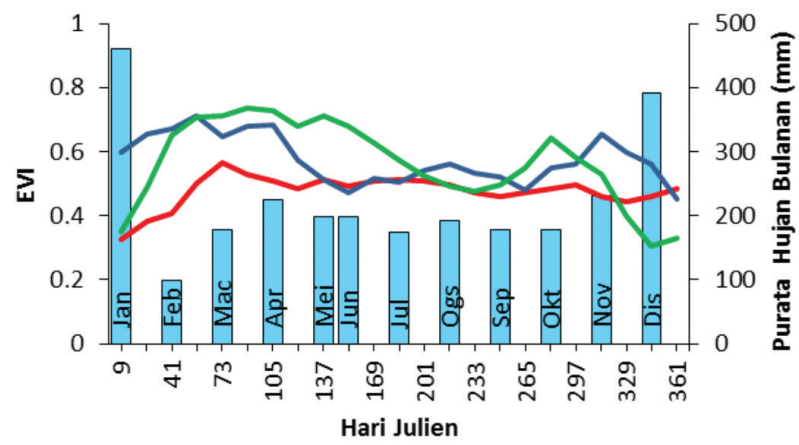

$\square$ Hujan $\longrightarrow$ Dipterokarp $\longrightarrow$ Kelapa Sawit $\longrightarrow$ Getah

RAJAH 2. Tren fenologi spesies tumbuhan terpilih dengan purata hujan bulanan sepanjang tahun 2007 


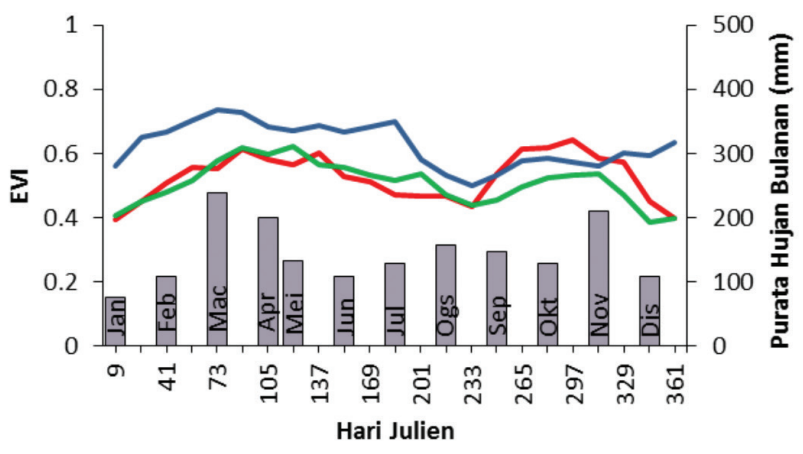

$\square$ Hujan —Dipterokarp —Kelapa Sawit —Getah

RAJAH 3. Tren fenologi spesies tumbuhan terpilih dengan purata hujan bulanan sepanjang tahun 2009

penerimaan hujan sepanjang tahun yang banyak, pokok hutan dipterokarpa sering mencapai ketinggian $50 \mathrm{~m}$ atau lebih dan lebih tinggi daripada hutan hujan di kawasan lain. Dipterokarpa juga memiliki kanopi mengembang, kebanyakannya padat dan sederhana padat serta berbentuk seperti bunga kubis dengan jarak yang sama antara kanopi pada dahan-dahan tersebut. Ciri-ciri tersebut diandaikan dapat mempengaruhi ketersediaan air di lantai hutan melalui kadar jatuhan langsung, aliran batang dan pintasan air hujan yang dialami oleh spesies hutan dipterokarpa di Johor.

Andaian tersebut dibuktikan oleh Nur Munirah et al. (2013) dengan ciri dan sifat pokok hutan dipterokarpa di Tasik Chini, Pahang telah memberi pengaruh terhadap jumlah jatuhan langsung, aliran batang dan pintasan hujan. Ciri pokok yang tinggi dan tekstur kulit yang licin (kurang halangan) mampu mengalirkan aliran batang yang lebih banyak. Kanopi pokok juga berfungsi untuk memerangkap dan menyimpan air hujan secara sementara sebelum mengalirkannya perlahan-lahan ke batang pokok dan secara tidak langsung proses susupan air hujan ke dalam tanah berlaku dengan lebih efektif. Jumlah hujan yang turun dalam sesuatu masa turut memberi pengaruh terhadap perilaku jatuhan langsung, aliran batang dan pintasan. Hubungan positif terbentuk antara jumlah hujan dengan jatuhan langsung dan aliran batang, seterusnya mempengaruhi nilai pintasan yang berlaku. Ini bermakna semakin tinggi jumlah hujan maka, semakin tinggi nilai jatuhan langsung dan pintasan hujan yang dicatatkan dan secara tidak langsung jumlah air serta kelembapan yang menyusup ke dalam lantai hutan turut meningkat.

Analisis korelasi mendapati wujud hubungan kuat antara EVI hutan dipterokarpa dengan tren hujan bulanan sepanjang 2007 dan hubungan sederhana sepanjang 2009. Kelewatan respons EVI selepas peristiwa hujan maksimum diramalkan turut memberi pengaruh kepada hasil korelasi negatif $r=-0.598(p<0.01)$ yang diperoleh pada tahun 2007 meskipun taburan hujan pada tahun tersebut adalah normal. Nilai EVI yang meningkat pada tempoh bulan yang menyusut jumlah hujannya jelas memberi gambaran bahawa penyusutan hujan membawa kepada pertambahan nilai EVI. Walaupun terdapat masa susulan pada EVI tahun 2009 namun, arah hubungan antara kedua pemboleh ubah adalah linear dengan nilai $r=0.497(p<0.05)$. Ini adalah kerana variasi yang dipamerkan oleh EVI dipterokarpa pada tahun tersebut adalah hampir seiringan dengan turun naik purata hujan sepanjang tahun tersebut meskipun terdapat kelewatan dan berbeza dengan EVI pada tahun 2007 yang menunjukkan tren malar hampir sepanjang tahun. Nilai $r^{2}$ yang diperoleh adalah 0.36 bagi 2007 dan 0.25 bagi 2009 . Nilai tersebut menjelaskan hanya sebahagian peratusan (36\% dan $25 \%$ ) daripada nilai EVI hutan dipterokarpa pada kedua-dua tahun adalah disebabkan oleh hujan dan sebahagian lagi diramalkan dipengaruhi oleh faktor lain seperti masa susulan.

Jika dibandingkan dengan tahun 2007, pengurangan hujan yang ketara untuk beberapa bulan, khususnya pada awal dan penghujung tahun 2009 didapati tidak memberi perbezaan yang ketara terhadap permulaan dan pengakhiran musim pertumbuhan antara keduadua tahun. Perbezaan purata hujan bulanan yang cukup besar dalam tempoh bulan terawal dan terakhir bagi kedua-dua tahun sama sekali tidak memberi kesan kelewatan yang ketara dengan permulaan dan akhir musim pertumbuhan hutan dipterokarpa berlaku pada bulan yang sama, iaitu Februari (permulaan musim) dan Disember (pengakhiran musim). Perbezaan permulaan dan pengakhiran musim pertumbuhan menyebabkan tempoh musim pertumbuhan pada 2007 (317 hari) adalah panjang sedikit berbanding 2009 ( 288 hari). Namun begitu, tempoh musim pertumbuhan bagi hutan dipterokarpa adalah yang paling lama berbanding dua spesies tumbuhan lain disebabkan sifat hutan yang malar hijau sepanjang tahun (Rajah 4(a)).

Kelapa Sawit Kelapa sawit dapat hidup dalam keadaan penerimaan hujan bulanan minimum sebanyak $150 \mathrm{~mm}$ sehingga mencecah $420 \mathrm{~mm}$ dengan syarat tanah adalah bersaliran baik (Ariffin et al. 2001). Dalam keadaan hujan yang banyak hasil kelapa sawit dijangkakan meningkat dan dalam keadaan air yang terhad pula hasil dijangkakan berkurangan (Ariffin et al. 2001; Cadena et al. 2006). Puah dan Madihah Jaafar (2011) mendapati hujan lebat dan suhu yang tinggi merupakan keadaan yang paling sesuai untuk penghasilan buah kelapa sawit di Pantai Barat Sabah. Walau bagaimanapun, pertambahan jumlah hujan sehingga membawa kepada banjir boleh menyebabkan kematian pokok kelapa sawit. Ini menunjukkan bahawa fenologi kelapa sawit juga responsif kepada hujan namun, tidak pada situasi penerimaan hujan yang terlalu ekstrem atau terlalu terhad sehingga boleh menjejaskan kitar pertumbuhannya.

Berdasarkan Rajah 2 dan 3, nilai EVI bagi kelapa sawit sepanjang dua tahun tersebut merupakan antara yang tertinggi berbanding dua spesies tumbuhan yang lain dengan purata 0.58 pada 2007 dan 0.63 pada 2009. Nilai EVI sepanjang 2009 adalah lebih tinggi berbanding 2007 walaupun terdapat banyak bulan sepanjang 2009 yang 

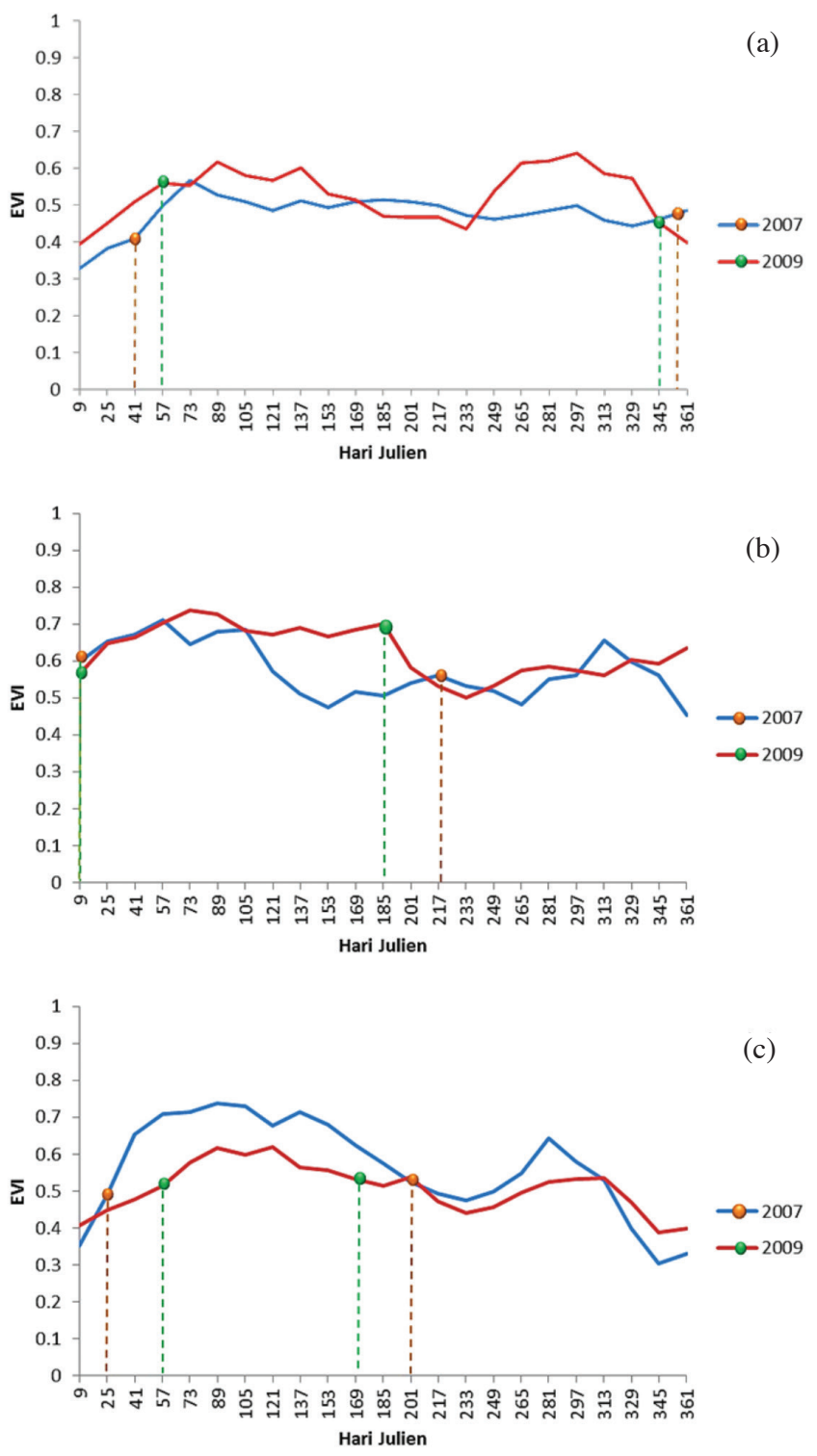

RAJAH 4. Perbezaan metrik fenologi di antara tahun 2007 dan 2009 bagi (a) hutan dipterokarpa, (b) kelapa sawit dan (c) getah

menerima hujan di bawah paras $150 \mathrm{~mm}$ (rata-ratanya di atas $100 \mathrm{~mm}$ kecuali pada bulan Januari) berbanding 2007, iaitu pada bulan Februari sahaja. Ini menunjukkan bahawa EVI kelapa sawit masih berada pada paras tinggi dalam situasi penerimaan hujan bulanan melebihi 100 mm dan tempoh musim kering $(<100 \mathrm{~mm})$ tidak melebihi dua bulan (Muhammad Rizal \& Tsan 2008; Ramli \& Mohd Basri 2011). Diandaikan bahawa nilai EVI masih berada pada paras tinggi dan hasil korelasi negatif ( $r=$ -0.083 ) tahun 2007 adalah disebabkan kesan masa susulan ekoran penerimaan jumlah hujan yang tinggi pada bulanbulan terdahulu. Curahan purata hujan yang tinggi pada Disember 2006 (603.4 mm) dan Januari 2007 (460.9 mm) menyebabkan EVI kelapa sawit tetap tekal untuk tempoh sekitar empat bulan (Januari hingga April) walaupun purata hujan pada bulan Februari menyusut sebanyak $362.1 \mathrm{~mm}$ berbanding bulan sebelumnya.
Selain itu, EVI kelapa sawit pada Januari 2009 adalah tertinggi berbanding dua spesies tumbuhan lain meskipun jumlah hujan pada bulan tersebut merupakan yang paling minimum sepanjang 2009. Perkara ini mungkin dapat dijelaskan melalui purata hujan sebanyak $207.8 \mathrm{~mm}$ pada Disember 2008 yang mampu membekalkan lembapan yang cukup selama dua bulan (Januari dan Februari) bagi kelapa sawit walaupun jumlah hujan pada bulan Januari berkurangan kepada $75.9 \mathrm{~mm}$. Penerimaan hujan tertinggi pada bulan Mac 2009 (239.3 mm) dan tekal untuk bulan berikutnya $(200.8 \mathrm{~mm})$ menyebabkan EVI kelapa sawit turut tekal untuk tempoh dua bulan seterusnya. Tren masa susulan turut dikesan pada penghujung tahun di mana EVI memuncak pada Disember, iaitu sebulan selepas penerimaan hujan yang agak tinggi pada November tahun tersebut (Rajah 3). Kajian oleh Puah dan Madihah Jaafar (2011) mendapati terdapat tiga bulan masa susulan sewaktu 
penghasilan tandan kelapa sawit di Pantai Barat Sabah selepas peristiwa hujan sepanjang 2005 hingga 2010 dan penghasilan tandan kelapa sawit berkorelasi sangat kuat dengan hujan.

Hubungan korelasi adalah sangat lemah dan tidak signifikan antara EVI kelapa sawit dengan tren hujan bulanan sepanjang 2007 ( $r=-0.083$ ) dan 2009 ( $r=0.137$ ). Ketidaksignifikan hasil korelasi yang diperoleh pada kedua-dua tahun menunjukkan terdapat keyakinan yang rendah untuk menyatakan bahawa hubungan EVI kelapa sawit dengan purata hujan bulanan sepanjang dua tahun tersebut mempunyai hubungan yang lemah. Masa susulan dijangkakan menjadi antara faktor lain yang mempengaruhi variasi EVI berdasarkan nilai $r^{2}$ yang rendah pada kedua tahun, masing-masing 0.01 (2007) dan 0.02 (2009).

Kajian oleh Cadena et al. (2006) mendapati respons tanaman kelapa sawit di Tumaco, Barat Daya Columbia terhadap hujan adalah lewat sehingga tiga bulan. Ini menunjukkan kesan masa susulan terhadap tahap kehijauan tanaman selepas daripada peristiwa hujan sememangnya dialami tanaman kelapa sawit. Sebagaimana hutan dipterokarpa, masa susulan juga dilihat menjadi sebahagian lagi faktor besar yang mempengaruhi variasi EVI kelapa sawit selain daripada taburan hujan berdasarkan nilai $r^{2}$ yang rendah, iaitu kurang daripada $3 \%$ untuk kedua tahun. Walaupun terdapat kelewatan pada tahap kehijauan tumbuhan bagi kedua tahun tersebut namun arah hubungan antara pemboleh ubah didapati linear pada 2009 dan songsang pada 2007. Perbezaan ini dipengaruhi oleh tempoh masa susulan yang lebih panjang pada 2007 dan lebih singkat pada 2009 ekoran daripada penerimaan jumlah hujan bulanan yang berbeza.

Walaupun terdapat bulan yang menerima hujan bulanan di bawah paras $100 \mathrm{~mm}$, namun musim kering pada 2007 dan 2009 hanya berlaku dalam tempoh satu bulan sahaja. Keadaan ini diandaikan menjadi faktor yang menyebabkan tidak wujud perbezaan yang besar antara panjang musim pertumbuhan kelapa sawit bagi kedua-dua tahun. Kesan daripada penerimaan jumlah hujan bulanan yang tinggi pada Disember 2006 dan 2008 menyebabkan permulaan musim pertumbuhan pada 2007 dan 2009 bermula pada hari yang sama, iaitu sejurus pada hari kesembilan ekoran daripada masa susulan yang mempengaruhi nilai EVI. Musim pertumbuhan kelapa sawit berakhir seiring dengan penyusutan nilai EVI pada hari ke217 bagi 2007 dan hari ke-185 bagi 2009 (Rajah 4(b)).

Pokok Getah Penerimaan purata hujan tahunan yang banyak pada 2007 menyebabkan nilai EVI pokok getah adalah lebih tinggi dan bervariasi berbanding tahun 2009 (Rajah 2 \& 3). Ini menunjukkan pokok getah adalah sangat responsif terhadap jumlah hujan yang banyak. Pokok getah merupakan pokok brevideciduous yang menggugurkan daun ketika melalui tempoh musim kering. Pokok getah perlu mempunyai akses kepada air yang mencukupi untuk memastikan daun-daun baru dapat tumbuh (Elliot et al. 2006; Williams et al. 2008). Pertumbuhan daun yang berterusan menyebabkan tahap kehijauan pokok getah sentiasa meningkat. Elliot et al. (2006) percaya bahawa pokok getah menunjukkan fenologi yang berbeza bergantung kepada imbangan air tempatan sewaktu musim kering.

Fenologi getah juga menunjukkan terdapat masa susulan ke atas tahap kehijauan pokok getah selepas peristiwa hujan bulanan maksimum pada kedua tahun. Hujan yang sangat banyak pada Disember 2006 (603.4 $\mathrm{mm}$ ) dan diikuti hujan bulanan maksimum pada Januari 2007 (460.9 mm) menyebabkan EVI getah pada 2007 meningkat secara drastik pada Februari dan tetap tinggi serta tekal untuk tempoh empat bulan seterusnya. Nilai EVI tanaman getah bagi tempoh tersebut merupakan yang tertinggi berbanding EVI bagi kelapa sawit dan hutan dipterokap. Hasil analisis korelasi menunjukkan bahawa EVI tanaman getah memiliki hubungan yang kuat dengan purata hujan sepanjang $2007(r=-0.677, p<0.01)$ dan sederhana pada tahun $2009(r=0.483, p<0.05)$. Namun begitu, kesan masa susulan yang lebih panjang tempohnya beserta peningkatan EVI yang drastik, selari dengan pengurangan hujan pada Februari dan bulan berikutnya menyebabkan arah hubungan antara kedua-dua pemboleh ubah pada 2007 adalah songsang. Masa susulan EVI pada tahun 2009 pula adalah lebih singkat, iaitu kira-kira dua bulan selepas peristiwa hujan maksimum pada Mac. Ini menunjukkan jangka masa susulan bagi EVI pokok getah adalah bergantung kepada jumlah hujan bulanan yang diterima dan secara tidak langsung turut mempengaruhi arah hubungan korelasi. Nilai $r^{2}$ pada kedua-dua tahun, iaitu 0.46 (2007) dan 0.23 (2009) sememangnya menunjukkan terdapat pengaruh lain yang menjelaskan variasi pada nilai EVI sepanjang tempoh tersebut dan diandaikan bahawa masa susulan merupakan antara faktor yang terangkum di dalamnya.

Selepas menerima jumlah hujan yang tinggi pada Januari 2007, musim pertumbuhan pokok getah terus bermula pada hari ke-25 dalam bulan tersebut. Musim pertumbuhan pada tahun 2009 pula lewat hampir satu bulan kerana jumlah hujan yang amat sedikit $(<100 \mathrm{~mm})$ pada Januari tahun tersebut masih belum cukup bagi pokok getah untuk memulakan musim pertumbuhannya. Selain itu, pengakhiran musim pertumbuhan pada tahun 2009 berakhir lebih awal (akhir Jun) berbanding pada 2007 apabila jumlah hujan pada bulan tersebut dilihat semakin berkurangan. Musim pertumbuhan pada tahun 2007 pula berakhir pada penghujung Julai sejurus tren kehijauan getah mula menunjukkan penurunan pada tempoh tersebut. Kelewatan permulaan musim pertumbuhan dan pengakhiran musim pertumbuhan yang lebih awal pada 2009 jelas menggambarkan bahawa pengurangan hujan berbanding tren kebiasaan sedikit sebanyak memberi kesan terhadap metriks fenologi pokok getah (Rajah 4(c)).

Secara keseluruhannya, pengaruh masa susulan daripada kelembapan tanah yang masih tersedia didapati memberi pengaruh ke atas pertumbuhan ketiga-tiga spesies tumbuhan kajian. Kelembapan yang tersimpan dan kekal di dalam tanih selepas satu-satu peristiwa hujan lebat menyebabkan spesies-spesies tumbuhan 
tersebut mampu mengekalkan tahap kehijauan dan panjang musim pertumbuhan untuk tempoh yang lebih lama walaupun tren penerimaan hujan pada bulan-bulan berikutnya berkurangan. Hasil kajian juga memaparkan potensi teknologi penderiaan jauh sebagai salah satu teknik menganalisis fenologi tumbuhan kerana tidak wujud teknologi selain daripada teknologi penderiaan jauh yang mampu melakukan pemantauan ke atas permukaan bumi secara berterusan dan dalam jangka masa panjang (Han 2012). Gabungan data EVI MODIS dan hujan memberikan satu alat bantu kajian yang berkesan bagi kajian pemonitoran respons tumbuhan terhadap hujan. Data EVI sebagai proksi kepada fenologi dan produktiviti tumbuhan sememangnya berkesan dalam kajian fenologi tumbuhan, khususnya di kawasan yang berkepadatan tumbuhan tinggi seperti kawasan hutan dan memberi keputusan yang lebih jitu berbanding NDVI disebabkan kelemahan NDVI yang mencapai tahap tepu ketika puncak musim pertumbuhan. Data EVI juga lebih fleksibel dan sesuai digunakan, khususnya bagi kajian yang memerlukan pemantauan kedinamikan tumbuh-tumbuhan di kawasan yang lebih luas.

\section{KESIMPULAN}

Hasil kajian menunjukkan perbezaan corak penerimaan hujan bulanan sepanjang 2007 dan 2009 memberi kesan ke atas tren fenologi hutan dipterokarpa, kelapa sawit dan pokok getah di negeri Johor. Meskipun pengaruh hujan pada kedua-dua tahun adalah kecil, namun ketigatiga spesies tumbuhan menunjukkan kebergantungan kepada hujan. Fenologi hutan dipterokarpa, kelapa sawit dan getah juga menunjukkan wujud masa susulan ke atas tahap kehijauan, khususnya selepas peristiwa hujan bulanan maksimum pada kedua tahun. Kesan masa susulan menyebabkan EVI bagi tiga spesies tumbuhan tetap tekal, bahkan meningkat untuk tempoh tertentu meskipun berlaku penyusutan jumlah hujan pada bulan berikutnya. Masa susulan merupakan antara faktor yang mempengaruhi hubungan songsang bagi EVI tiga spesies tumbuhan dengan purata hujan bulanan pada 2007. Wujud pengurangan tempoh musim pertumbuhan bagi tiga spesies tumbuhan pada 2009 dan pengurangan yang besar berlaku pada pokok getah yang merupakan spesies paling responsif dan sensitif terhadap penyusutan jumlah hujan. Pergantungan fenologi tumbuhan terhadap purata hujan bulanan menunjukkan bahawa perubahan iklim mungkin mempunyai pengaruh yang besar ke atas fenologi tumbuh-tumbuhan di rantau ini. Kajian lanjutan menggunakan set data jangka panjang dengan resolusi spatial yang tinggi bagi EVI dan hujan perlu dilakukan untuk memahami kesan perubahan iklim ke atas pertumbuhan tumbuh-tumbuhan.

\section{PENGHARGAAN}

Artikel ini dapat dihasilkan melalui penyelidikan yang disokong oleh dana penyelidikan berkod GGPM-2014-031, UKM.

\section{RUJUKAN}

Ariffin Tawang, Tengku Ariff Tengku Ahmad \& Mohd. Yusof Abdullah. 2001. Stabilization of upland agriculture under El Nino induced climatic risk: Impact assessment and mitigation measures in Malaysia. Kertas kerja No. 61. Bogor, Indonesia: CGPRT Centre.

Cadena, M.C., Devis-Morales, A., Pabon, J.D., Malikov, I., Reyna-Moreno, J.A. \& Ortiz, J.R. 2006. Relationship between the 1997/98 El Nino and 1999/2001 La Nina events and oil palm tree production in Tumaco, Southwestern Colombia. Advances in Geosciences, European Geosciences Union (EGU) 6: 195-199.

Corlett, T.R. \& Primack, R. 2005. Tropical Rain Forests: An Ecological and Biogeographical Comparison. Malden, Massachusetts: Blackwell Science Ltd.

Elliot, S., Baker, P.J. \& Borchert, R. 2006. Leaf flushing during the dry season: The paradox of Asian monsoon forests. Global Ecology and Biogeography 15: 248-257.

Farooq Ahmad. 2012. Phenologically-tuned MODIS NDVI based time series (2000-2012) for monitoring of vegetation and climate change in North-Eastern Punjab, Pakistan. Global Journal of Human Social Science Geography \& Environmental Geosciences 12(13): 1-19.

Han, Q. 2012. Remote sensing-based quantification of spatial and temporal variation in canopy phenology of four dominant tree species. Tesis Ijazah Sarjana, Faculty of Geo-information Science and Earth Observation, University of Twente (tidak diterbitkan).

Jabatan Perancangan Bandar dan Desa Semenanjung Malaysia. 2012. Laporan Guna Tanah 2012: Guna Tanah Semasa Rancangan-rancangan Tempatan Negeri Johor.

Menzel, A., Sparks, T.H., Estrella, N., Koch, E., Aasa, A., Ahas, R., Alm-Kübler, K., Bissolli, P., Braslavskà, O., Briede, A., Chmielewski, F.M., Crepinsek, Z., Curnel, Y., Dahl, A.S., Defila, C., Donnelly, A., Filella, Y., Jatczak, K., Måge, F., Mestre, A., Nordli, O.Y., Peñuelas, J., Pirinen, P., Remišová, V., Scheifinger, H., Striz, M., Susnik, A., Van Vliet, A.J.H., Wielgolaski, F.E., Zach, S. \& Zust, A. 2006. European phenological response to climate change matches the warming pattern. Global Change Biology 12(10): 1969-1976.

Muhammad Rizal \& Tsan, F.Y. 2008. Rainfall impact on oil palm production and OER at Felda Triang 2. Universiti Teknologi MARA (UiTM). http://versys.uitm.edu.my/prisma/view/ viewPdf.php?pid=15908. Diakses pada 10 Mac 2015.

Moreau, I. \& Defourny, P. 2012. The vegetation phenology detection in Amazon tropical evergreen forests using SPOTVEGETATION 11-y time series. Geoscience and Remote Sensing Symposium (IGARSS), IEEE International July 22-27.

Ng, F.S.P., Low, C.M. \& Mat Asri, N.S. 1990. Endemic Trees of the Malay Peninsular. Research Pamphlet No. 106. Forest Research Institute Malaysia.

Nur Munirah Abdullah, Mohd Ekhwan Toriman, Haslinur Md. Din, Nor Azlina Ab. Aziz, Mohd Khairul Amri Kamarudin, Nurul Syazwani Abdul Rani, Frankie Marcus Ata, Mohd Hafiz Saad, Noraini Wahida Abdullah, Mushrifah Idris \& Nor Rohaizah Jamil. 2013. Pengaruh faktor keruangan dan masa dalam menentukan kadar pintasan hujan di kanopi hutan dipterokarpa, Tasik Chini, Pahang. The Malaysian Journal of Analytycal Science 17(1): 11-23.

Phompila, C., Lewis, M., Clarke, K. \& Ostendorf, B. 2014. Monitoring temporal vegetation changes in Lao tropical forests. IOP Conf. Series: Earth and Environmental Science 20: 755-1315. 
Puah, P.W. \& Madihah Jaafar Sidek. 2011. Impacts of rainfall, temperature and recent El Niños on fisheries and agricultural products in the West Coast of Sabah (2000-2010). Borneo Science 28(3): 73-85.

Ramli Abdullah \& Mohd Basri Wahid. 2011. World palm oil supply, demand, price and prospect: Focus on Malaysian and Indonesian palm oil industry. Malaysia Palm Oil Board (MPOB). http://mpoc.org.my/upload/ WorldPalmOil_SupplyDemandPriceProspects MalaysianIndonesianIndustry_FullReport.pdf. Diakses pada 2 Februari 2015.

Senf, C., Pflugmacher, D., Linden, S. \& Hostert, P. 2013. Mapping rubber plantations and natural forests in Xishuangbanna (Southwest China) using multi-spectral phenological metrics from MODIS time series. Remote Sensing 5: 2795-2812.

Sakai, S. 2001. Phenological diversity in tropical forests. The Society of Population Ecology and Springer-Verlag Tokyo 43: 77-86.

Sharifah Haslinda. 2011. Analisis keberkesanan penuaian air hujan di Zoo Negara, Hulu Klang, Selangor. Latihan Ilmiah, Fakulti Kejuruteraan Awam, Universiti Teknologi Malaysia (tidak diterbitkan).

Sykes, M.T. 2009. Climate Change Impacts: Vegetation. Encyclopedia of Life Sciences (ELS). Chichester: John Wiley \& Sons, Ltd.

Tan, B., Morisette, J.T., Wolfe, R.E., Gao, F., Ederer, G.A., Nightingale, J. \& Pedelty, J.A. 2008. Vegetation phenology metrics derived from temporally smoothed and gap-filled MODIS data. IGRSS 2008. pp. 593-596.
Van Shaik, C.P., Terborgh, J.W. \& Wright, S.J. 1993. The phenology of tropical forests: Adaptive significance and consequences for primary consumers. Annual Review of Ecology and Systematics 24: 353-377.

Williams, L.J., Bunyavejchewing, S. \& Baker, P.J. 2008. Deciduousness in a seasonal tropical forest in Western Thailand interannual and intraspecific variation in timing, duration and environmental cues. Oecologia 155: 571-582.

Yu, X., Wang, Q., Yan, H., Wang, Y., Wen, K., Zhuang, D. \& Wang, Q. 2014. Forest phenology dynamics and its responses to meteorological variations in Northeast China. Advances in Meteorology 2014: Article ID. 592106.

Zhang, X., Friedl, M.A., Schaaf, C.B., Strahler, A.H., Hodges, J.C.F., Gao, F., Reed, B.C. \& Huete, A. 2003. Monitoring vegetation phenology using MODIS. Remote Sensing of Environment 84: 471-475.

Pusat Pengajian Sosial, Pembangunan \& Persekitaran

Fakulti Sains Sosial dan Kemanusiaan

Universiti Kebangsaan Malaysia

43600 UKM Bangi, Selangor Darul Ehsan

Malaysia

*Pengarang untuk surat-menyurat; email: amirahaudadimadzen@ yahoo.com

Diserahkan: 27 November 2015

Diterima: 23 Jun 2016 